\title{
MANAJEMEN HUBUNGAN MASYARAKAT DI SEKOLAH / MADRASAH
}

\author{
Rahmalia Syifa Miasari ${ }^{1}$,Tanti Julianti ${ }^{2,}$ Andrean Pangestu ${ }^{3,}$ Suprinanto ${ }^{4}$ \\ e-mail : tantijulianti50@gmail.com \\ Universitas Ahmad Dahlan ${ }^{1}$, Universitas Ahmad Dahlan ${ }^{2}$, \\ Universitas Ahmad Dahlan ${ }^{3}$, Universitas Ahmad Dahlan ${ }^{4}$
}

\begin{abstract}
ABSTRAK
Ruang pendidikan dan masyarakat adalah iklim hidup yang tidak bisa dipisahkan. Sekolah adalah tempat untuk belajar, sedangkan iklim daerah setempat adalah tempat untuk konsekuensi dari proses pelatihan dan pertunjukan di sekolah. Apa dan bagaimana mewujudkannya di sekolah senantiasa dikaitkan dengan nilainya untuk lebih mengembangkan kehidupan dan kehidupan di kancah publik. Kelompok masyarakat sebagai salah satu pemilik sekolah menjunjung tinggi dan mengambil bagian dalam pengembangan lebih lanjut pengajaran di sekolah. Sekolah dan jaringan tetap berhubungan terus-menerus. Iklim edukatif adalah segala yang ada dan terjadi dalam interaksi instruktif, karena kumpulan materi atau iklim edukatif ikut serta dalam upaya membina diri. Untuk situasi ini, pelatihan para eksekutif berfokus pada iklim sebagai manusia, khususnya daerah setempat dalam memahami proses pengajaran yang berkualitas

Kata Kunci : Pendidikan, Manajemen, Sekolah
\end{abstract}

\begin{abstract}
Abstrack
Educational space and society are a living climate that cannot be separated. The school is a place for learning, while the local climate is a place for the consequences of the training and performance processes in schools. What and how to make it happen in schools is always associated with its value to further develop life and life in the public arena. Community groups as one of the owners of the school uphold and take part in the further development of teaching in schools.

Schools and networks stay in constant touch. An educational climate is everything that exists and occurs in instructive interactions, because a collection of materials or an educative climate participates in self-development efforts. For this situation, the training of executives focuses on the climate as human beings, especially the local area in understanding the quality teaching process.

Keywords : Education, Management, School
\end{abstract}




\section{PENDAHULUAN}

Keadaan rumit yang tak terhindarkan dari pergantian peristiwa di seluruh dunia, yang dipisahkan oleh kemajuan di setiap pusat kehidupan, mempengaruhi keadaan darurat etika di semua kalangan, baik di kalangan pelajar maupun di kalangan lokal. Hal ini terlihat dari banyaknya pelanggaran yang tidak terkendali, seperti tawuran antar mahasiswa, kasus penyerangan bahkan pembunuhan.

Hubungan antara sekolah dan daerah setempat awalnya muncul di AS, ketika individu meneliti pentingnya pelatihan untuk permintaan dan perbaikan daerah lingkungan setempat. Masyarakat selama beberapa waktu dipandang sebagai bagian penting dari sekolah. Jadi Ki Hajar Dewantara mengungkapkan bahwa mengajar adalah kewajiban bersama yang dikenal dengan Tiga Tempat Latihan, baik itu keluarga, sekolah (pemerintah) dan masyarakat tertentu. semua pertemuan (Keluarga, sekolah dan lingkungan) secara sinergis dan terpadu, maka pada saat itu, tujuan tidak akan tercapai secara optimal.

Hubungan masyarakat dengan sekolah adalah kebutuhan bersama untuk meningkatkan kualitas sekolah dan terjalinnya komunikasi antara sekolah dan masyarakatnya. Proyek sekolah dan latihan sekolah yang diidentifikasi dengan area lokal memerlukan bantuan dan dukungan wali dan area lokal untuk mencapai tujuan sekolah. Dengan landasan hubungan yang bersahabat antara sekolah dan daerah setempat, sekolah dapat diterima secara umum oleh daerah setempat. Jika organisasi instruktif dapat diterima secara umum secara lokal, gambaran mereka akan meningkat. Dalam Undang-Undang Republik Indonesia nomor 20 tahun 2003 pasal 7 ayat 1 yang menyatakan bahwa wali mempunyai hak untuk ikut serta dalam memilih satuan ajar dan memperoleh data tentang giliran ajar anak-anaknya. Dengan cara ini, sekolah memberikan administrasi data instruktif dan data latihan di sekolah. Karakter organisasi edukatif dan kearifan masyarakat nantinya akan membentuk citra sekolah. terbuka yang adil dapat diterima dan sah.

Sekolah/madrasah yang berkualitas harus dididik ke wilayah lokal yang lebih luas dengan mengiklankan para eksekutif sekolah. Jadi anggapan yang bagus dan gambaran positif dari daerah dapat diakui dengan iklan yang dapat diterima para eksekutif. Dari informasi, kenyataan, dan spekulasi yang membantu pentingnya periklanan para eksekutif dalam membangun citra sekolah.

\section{METODE PENELITIAN}

Penelitian ini dilakukan dengan menggunakan metode library research, metode perkembangan, serta metode korelasional. Pengangkatan materi mengenai Manajemen Hubungan Masyarakat di Sekolah/Madrasah, pencarian data melalui studi pustala mengenai bagaimana konsep manajemen dilakukan masyarakat hubungannya dengan sekolah. Pendekatan kualitatif digunakan dalam menghubungkan pengaruh-pengaruh manajemen pendidikan yang berbeda antara disekolah dan di masyarakat. Metode korelasional mayoritas digunakan untuk mengetahui hal apa saja yang diterapkan pada manajemen pendidikan yang saat ini masih digunakan dalam penyelenggaraan di sekolah.

\section{HASIL DAN PEMBAHASAN \\ Pengertian menejemen}

Manajemen berasal dari bahasa latin, secara tegas dari awal kata manus yang berarti tangan dan setuju yang berarti melakukan. Katakata ini dikonsolidasikan menjadi managere yang berarti mengelola. Managere diterjemahkan ke dalam bahasa Inggris untuk mengawasi (aktivitas kata), dewan (benda), dan direktur untuk orang yang melakukannya. Dewan diterjemahkan dalam bahasa Indonesia sebagai ketua s (Salehah, 2018)

Administrasi instruktif adalah gerakan atau serangkaian latihan sebagai bisnis berorientasi komunitas interaksi eksekutif dari kumpulan individu yang merupakan individu dari asosiasi edukatif, untuk mencapai tujuan instruktif yang baru-baru ini dilakukan, untuk menjadi sukses dan efektif. Administrasi instruktif sebagai interaksi atau kerangka eksekutif. Para pelaksana latihan di lembaga edukatif berharap dapat melaksanakan proses pendidikan dan pembelajaran (KBM) yang layak(Kuntoro, 2019)

Melalui pengembangan semua bagian sekolah, pelatihan unggulan jika setiap siswa tumbuh secara ideal yang ditunjukkan oleh kapasitasnya dan dapat menumbuhkan kapasitas dan keterampilan untuk mengerjakan sifat pengajaran. Pembelajaran yang baik akan mengarahkan siswa menuju pembentukan pribadi Indonesia seutuhnya. Dalam mengerjakan sifat persekolahan, ada beberapa teknik yang digunakan dalam mengerjakan sifat pengajaran, khususnya administrasi mutu terkoordinasi yang biasanya disebut Administrasi Mutu Absolut (TQM)(JAMALUDDIN ISKANDAR, 2017) 
Pendidikan merupakan usaha peningkatan publik yang dapat dilihat dari sifat SDM yang diklaim, perspektif ini dilihat dari info, interaksi dan hasil hanya sebagai hasil dari sekolah. Tugas sekolah untuk memperkuat sifat SDM ditopang oleh desain administrasi yang terorganisir dalam sistem pembelajaran siswa dalam mengerjakan sifat pelatihan.

Menejemen pendidikan sebagai siklus atau kerangka kerja dewan. Latihan dewan dalam kerangka sekolah berencana untuk melaksanakan proses pengajaran dan pembelajaran yang layak.SDM dianggap sebagai kualitas yang muncul dari potensi mereka dalam sebuah asosiasi. SDM yang hebat pasti dapat menyampaikan suatu asosiasi untuk mencapai tujuannya. Tanpa SDM yang hebat, tidak diragukan lagi sulit untuk mencapai tujuan yang berwibawa. Ini adalah salah satu elemen aset manusia dewan. Dewan adalah metode yang terlibat dengan mengatur, menyusun, mengkoordinasikan dan mengamati upaya individu hierarkis dan pemanfaatan aset yang berbeda untuk mencapai tujuan otoritatif. Oleh karena itu, semua individu atau bagian dari yayasan pendidikan yang layak sebagai bagian dari suatu perkumpulan harus melaksanakan administrasi yang baik dengan tujuan agar tujuan visi dan misi sekolah tercapai dengan tepat dan tepat waktu. Pekerjaan administrasi dibagi menjadi 2 (dua) jenis, yaitu administrasi ketenagakerjaan dan administrasi pengaturan yang lebih mementingkan penetapan tujuan dan kemudian mengatur, mengatur, dan mengelola latihan yang difasilitasi untuk mencapai tujuan. Sementara administrasi yang dapat digunakan menggabungkan lebih banyak latihan untuk membangkitkan, mengatur, dan berbicara dengan perwakilan untuk membimbing mereka mencapai hasil yang menarik.

\section{Hubungan Manajemen Sekolah / Madrasah} dan Masyarakat

Hubungan Sekolah dan masyarakat adalah iklim hidup yang tidak bisa dipisahkan. Sekolah adalah tempat untuk belajar, sedangkan iklim daerah setempat adalah tempat untuk konsekuensi dari proses pelatihan dan pertunjukan di sekolah. Apa dan bagaimana mewujudkannya di sekolah senantiasa dikaitkan dengan nilainya untuk lebih mengembangkan kehidupan dan kehidupan di kancah publik. Kelompok masyarakat sebagai salah satu pemilik sekolah menjunjung tinggi dan mengambil bagian dalam pengembangan lebih lanjut pelatihan di sekolah. Sekolah dan jaringan tetap berhubungan terus-menerus(Umar, 2016)

Ruang Pendidikan adalah kerangka terbuka terhadap iklim, termasuk daerah setempat yang menjunjungnya. Sebagai kerangka terbuka, sekolah tidak bisa melepaskan diri karena, dalam hal ini dilakukan, itu menyiratkan bahwa sekolah telah menuju ke tepi stagnasi dan stagnasi karena menantang komitmen hukum reguler. Seperti kerangka terbuka, sekolah juga secara konsisten siap untuk mengakui individu lokal, pemikiran yang disampaikan, kebutuhan mereka dan kualitas yang ada di arena publik. Lagi pula, daerah setempat juga terbuka untuk menerima dan mewajibkan latihan sekolah. keuntungan dari daerah setempat.

Dalam proses hubungan manajemen sekolah dan masyarakat mempunyai 3 cara kerja yaitu antara lain :

Hubungan edukatif, koneksi yang bermanfaat sejauh mengajar anak didik, antara pengajar di sekolah dan wali dalam keluarga. Hubungan ini direncanakan agar tidak ada perbedaan standar atau bahkan pertentangan yang menimbulkan pertanyaan dalam mentalitas dan perspektif siswa. Teknik ini harus dimungkinkan dengan mengadakan pertemuan sesekali antara instruktur dan wali siswa sebagai individu dewan wali atau semacamnya, pertemuan rumah orangorang pendidik di luar waktu pendidikan atau mengadakan pertemuan antara instruktur dan wali siswa per kelas untuk mengadakan pertemuan terbuka. pertukaran pada isu-isu instruktif diidentifikasi dengan sekolah.

Hubungan kultural, Hubungan ini merupakan hubungan bisnis yang membantu antara sekolah dan daerah setempat yang memungkinkan satu sama lain untuk menumbuhkan dan membina cara hidup daerah setempat di mana sekolah itu berada. Dalam pergaulan ini, dipercaya bahwa sekolah akan benar-benar ingin menjadi tengah dan tercurah pada mata air standar kehidupan (agama, akhlak, akhlak, sosial, dll).

Hubungan institusional, Hubungan ini adalah hubungan yang bermanfaat antara sekolah dan organisasi atau kantor otoritas lainnya, baik swasta maupun pemerintah. Misalnya, hubungan antara sekolah dan fokus kesejahteraan, pemerintah terdekat, administrasi pedesaan, pasar, dll diselesaikan secara sukarela untuk meningkatkan dan mendorong pelatihan.

Manajemen humas dapat dilihat sebagai pemanfaatan batas utama (menempatkan, 
menggabungkan,

mengartikan, mengkoordinasikan dan survei) dalam latihan periklanan. Dewan promosi/iklan sekolah memiliki kemampuan untuk memimpin penyelidikan, mengumpulkan, mengarahkan dan mensurvei berbagai praktik korespondensi yang dijunjung oleh afiliasi. Berikutnya adalah hubungan sekolah-wilayah, proses pemuatan:18 Tindakan ini mencakup: (a) menggambarkan hubungan sekolah-wilayah dengan jelas, (b) menetapkan program sesuai dengan sarana dan tujuan dan menetapkan prosedur peningkatan proyek , (c) menentukan jadwal kegiatan hubungan sekolah dan lingkungan hingga waktu buka di sekolah dan (d) menyimpulkan sumber dan ukuran penggunaan yang dibutuhkan untuk setiap pembangunan.

Keterkaitan antara sekolah dan lingkungan sekitar merupakan lingkungan kehidupan yang tidak dapat dipisahkan. Sekolah merupakan tempat belajar, sedangkan lingkungan sekitar merupakan tempat berlangsungnya proses persiapan dan pelaksanaan di sekolah. Apa dan bagaimana mewujudkannya di sekolah selalu dikaitkan dengan nilainya untuk juga menumbuhkan kehidupan dan kehidupan di lapangan publik. Silaturahmi lokal sebagai salah satu pemilik sekolah menjaga dan mengambil bagian dalam peningkatan lebih lanjut persiapan di sekolah.Sekolah dan jaringan tetap berhubungan terus-menerus(Umar, 2016)

Sekolah merupakan kerangka terbuka terhadap iklim, termasuk daerah setempat yang menjunjungnya. Sebagai kerangka kerja terbuka, sekolah tidak dapat memisahkan diri karena, dalam hal ini dilakukan, itu menyiratkan bahwa sekolah telah pergi ke tepi stagnasi dan stagnasi karena menantang komitmen hukum reguler. Seperti kerangka kerja terbuka, sekolah juga secara konsisten siap untuk mengakui individu lokal, pemikiran yang disampaikan, persyaratan mereka dan kualitas yang ada di arena publik. Lagi pula, daerah setempat juga terbuka untuk menerima dan mewajibkan latihan sekolah. keuntungan dari masyarakat.

Sekolah merupakan kerangka terbuka terhadap iklim, termasuk daerah setempat yang menjunjungnya. Sebagai kerangka kerja terbuka, sekolah tidak dapat memisahkan diri karena, dalam hal ini dilakukan, itu menyiratkan bahwa sekolah telah pergi ke tepi stagnasi dan stagnasi karena menantang komitmen hukum reguler. Seperti kerangka kerja terbuka, sekolah juga secara konsisten siap untuk mengakui individu lokal, pemikiran yang disampaikan, persyaratan mereka dan kualitas yang ada di arena publik. Lagi pula, daerah setempat juga terbuka untuk menerima dan mewajibkan latihan sekolah. keuntungan dari masyarakat.

Dalam proses hubungan manajemen sekolah dan masyarakat mempunyai 3 cara kerja yaitu antara lain :

1. Hubungan Edukatif, koneksi yang bermanfaat sejauh mengajar siswa, antara pengajar di sekolah dan wali dalam keluarga. Hubungan ini direncanakan agar tidak ada perbedaan standar atau bahkan pertentangan yang menimbulkan pertanyaan dalam mentalitas dan perspektif siswa. Teknik ini harus dimungkinkan dengan mengadakan pertemuan sesekali antara instruktur dan wali siswa sebagai individu dewan wali atau semacamnya, pertemuan rumah orang-orang pendidik di luar waktu pendidikan atau mengadakan pertemuan antara instruktur dan wali siswa per kelas untuk mengadakan pertemuan terbuka. pertukaran pada isu-isu instruktif diidentifikasi dengan sekolah.

2. Hubungan Kultural, Hubungan ini merupakan hubungan bisnis yang membantu antara sekolah dan daerah setempat yang memungkinkan satu sama lain untuk menumbuhkan dan membina cara hidup daerah setempat di mana sekolah itu berada. Dalam pergaulan ini, dipercaya bahwa sekolah akan benarbenar ingin menjadi tengah dan tercurah pada mata air standar kehidupan (agama, akhlak, akhlak, sosial, dll).

3. Hubungan Institusional, Hubungan ini adalah hubungan yang bermanfaat antara sekolah dan organisasi atau kantor otoritas lainnya, baik swasta maupun pemerintah. Misalnya, hubungan antara sekolah dan fokus kesejahteraan, pemerintah terdekat, administrasi pedesaan, pasar, dll diselesaikan secara sukarela untuk meningkatkan dan mendorong pelatihan.

Periklanan Para eksekutif dapat dipandang sebagai pemanfaatan kapasitas dewan (mengatur, mengkoordinasikan, memanfaatkan, mengarahkan dan menilai) dalam latihan periklanan. Periklanan para eksekutif memiliki kapasitas untuk mengarahkan pemeriksaan, mengatur, 
melaksanakan dan menilai berbagai latihan yang didukung oleh asosiasi.

Berikutnya adalah hubungan sekolahdaerah, interaksi dewan, pengaturan ini mencakup:

a. Jelaskan dengan jelas hubungan antara sekolah dan masyarakat

b. Memutuskan program sesuai sarana dengan tujuan dan memutuskan sistem perbaikan program

c. Tentukan jadwal latihan sekolah dan area lokal sesuai dengan waktu yang tersedia di sekolah

d. Tentukan sumber dan ukuran pengeluaran yang diperlukan untuk setiap tindakan pemilahan.

Manajemen humas dapat dilihat sebagai penggunaan kapasitas eksekutif (mengatur, menyusun, mengartikan, mengarahkan dan menilai) dalam kegiatan humas . Dewan periklanan /humas sekolah memiliki kapasitas untuk memimpin eksplorasi, mengatur, melaksanakan, dan menilai berbagai latihan korespondensi yang didukung oleh asosiasi. Berikutnya adalah hubungan sekolah-daerah, proses dewan. Pengaturan ini mencakup: (a) dengan jelas mencirikan hubungan sekolahdaerah, (b) memutuskan program sesuai dengan cara dan tujuan dan memutuskan teknik perbaikan proyek, (c ) memutuskan jadwal praktik hubungan sekolah dan lingkungan sesuai dengan waktu yang tersedia di sekolah dan (d) menyimpulkan sumber dan ukuran penggunaan yang diperlukan untuk setiap pengembangan.

Keterkaitan antara sekolah atau madrasah dengan masyarakat merupakan suatu organisasi komunikasi yang dicari sekolah untuk diakui di tengah-tengah masyarakat untuk mendapatkan cita-cita, kasih sayang dari daerah setempat. Juga, buat kemajuan menuju upaya terkoordinasi untuk kebikan bersama, atau secara khusus bagi sekolah atau madrasah penjalin hubungan tersebut bisa tetap eksis. Keterkaitan antara sekolah atau madrasah dengan daerah merupakan interaksi korespondensi antara sekolah atau madrasah dengan daerah setempat untuk membangun pemahaman masyarakat tentang persyaratan dan latihan instruktif serta memberdayakan minat dan kerjasama daerah dalam meningkatkan dan menciptakan sekolah atau madrasah.(Afriansyah, 2019)

Hubungan sekolah dengan masyarakat adalah gagasan yang mencakup penghibur edukatif, administrator, instruktur, siswa, wali dan daerah dalam menciptakan sekolah atau lembaga pendidikan terkait. Kehadiran sekolah sangat terkenal dengan daerah setempat, terutama asosiasi yang menyenangkan dengan daerah setempat. Semakin baik hubungan yang menyenangkan antara sekolah dan daerah setempat, semakin baik pergantian acara dan kehadiran sekolah akan.(Sarwanto, 2016)

Banyak individu memutuskan hubungan sekolah/madrasah dengan daerah setempat dari perspektif yang terbatas. Mereka berpendapat bahwa hubungan yang membantu hanya sejauh mengajar anak-anak sesekali. Namun lama wali dan instruktur di sekolah/madrasah telah bekerja sama untuk anak-anak/muridnya.(Abdussalam et al., 2018)

Sekolah/madrasaah dituntun untuk jaminan dan kemajuan sosial, dengan menjadi penghibur yang berfungsi dalam perbaikan masyarakat. Sejalan dengan itu, sekolah/madrasah merupakan bagian yang tidak terpisahkan dari wilayah setempat, bahkan pengembangan dan peningkatan sekolah/madrasah sesuai dengan arahan wilayah setempat. Sepanjang pengembangan kelembagaannya, sekolah/madrasah harus dipastikan ditampilkan untuk mengatasi persoalan-persoalan lokal yang melingkupinya dengan tujuan agar tercipta partisipasi yang menyenangkan antara keduanya.

Hubungan antara sekolah atau madrasah dengan masyarakat memiliki hubungan yang nyaman dalam mencapai tujuan madrasah atau madrasah secara sukses dan produktif. Selain itu, sekolah juga harus menjunjung tinggi tujuan administrasi atau mengatasi masalah daerah setempat, terutama kebutuhan edukatif. Dengan cara ini, madrasah wajib memberikan data tentang tujuan, proyek, persyaratan dan kondisi. Kemudian lagi, madrasah juga harus mengetahui secara jelas apa persyaratan, asumsi, dan arahan daerah setempat, khususnya untuk madrasah. Jika hubungan sekolah/madrasah dengan masyarakat berjalan secara positif, rasa kewajiban dan investasi daerah dalam memajukan sekolah juga akan dapat diterima dan tinggi. Untuk menjalin hubungan dan partisipasi yang baik antara sekolah/madrasah dan daerah setempat, penting untuk mengetahui dan memiliki citra yang jelas tentang sekolah/madrasah yang bersangkutan. 
Melalui hubungan kekeluargaan diyakini tercapai tujuan hubungan sekolah/madrasah dengan daerah, khususnya pelaksanaan proses pengajaran sekolah dengan cara yang bermanfaat, berhasil, dan cakap untuk menghasilkan alumni yang berkualitas. , untuk situasi ini, cenderung dilihat dari dominasi ilmu pengetahuan mahasiswa.(Fithriani, 2019)

\section{KESIMPULAN}

Manajemen Humas dapat diartikan sebagai penerapan fungsi-fungsi manajemen (Perencanaan, Pengorganisasian, Penafsiran, Pemimpin dan Evaluasi) pada kegiatan humas. Manajemen humas sekolah mempunyai fungsi berarti melakukan penelitian, perencanaan, pelaksanan dan evaluasi terhadap kegiatan komunikasi yang di sponsori oleh organisasi. Berikut adalah proses manajemen hubungan sekolah dan masyarakat, perencenaan mencakup; a. Menentukan hubungan sekolah dan masyarakat secara jelas, b. Menentukan program sesuai sarana dengan tujuan serta menentukan prosedur pengembangan program, c. Menentukan jadwal kegiatan hubungan sekolah dan masyarakat sesuai dengan waktu yang tersedia disekolah, $\mathrm{d}$. Menentukan sumber dan besarnya biaya yang dbutuhkan untuktiap kegiatan pengorganisasian.

\section{DAFTAR PUSTAKA}

JAMALUDDIN ISKANDAR. (2017). PENERAPAN MANAJEMEN STRATEGI DALAM PENINGKATAN MUTU MADRASAH. JURNAL IDAARAH, VOL. I, NO(36), 268-274.

https://doi.org/10.1097/01.ede.0000417270. 95439.63

Kuntoro, A. T. (2019). Manajemen Mutu Pendidikan Islam. Jurnal Kependidikan, 7(1), 84-97. https://doi.org/10.24090/jk.v7i1.2928

Prayoga, A. S. (2016). Kontribusi Penjas dalam Pengembangan Sekolah Ramah Anak untuk Anak Disabilitas. Open Jurnal System, 36(01).

Salehah, A. (2018). Manajemen Kearsipan Dalam Ketatausahaan Di Min 3 Pringsewu. 1-114.

Umar, M. (2016). Manajemen Hubungan Sekolah Dan Masyarakat Dalam Pendidikan. JURNAL EDUKASI: Jurnal Bimbingan Konseling, 2(1), 18. https://doi.org/10.22373/je.v2i1.688

Abdussalam, Bahari, Y., \& Zakso, A. (2018). Hubungan Sekolah Dengan Masyarakat
Pada Ma Al-Aziz Parit Timur Pasak Sungai Ambawang Kubu Raya. Jurnal Untan, 1-15. Afriansyah, H. (2019). Administrasi Hubungan Sekolah dengan Masyarakat. 1-4. https://doi.org/10.31227/osf.io/cxtvz

Fithriani, F. (2019). Manajemen Hubungan Masyarakat Dengan Lembaga Sekolah. Intelektualita, 5(02), 1-16.

Sarwanto. (2016). Manajemen Hubungan Sekolah Dengan Masyarakat Di Madrasah Tsanawiyah (MTs) NEGERI 2 Bandar Lampung. 1-23. 